\title{
Memory, shame and dignity
}

\author{
GöRan Rosenberg
}

$\mathrm{R}$

ereading reports and comments in Swedish newspapers about the anti-Jewish measures in Germany after the Nazi takeover in I933, one will not fail to note the deep sense of shock, dismay and even disbelief that they convey - as if no-one had truly believed that the violent anti-Jewish rhetoric of the Nazi movement would lead to corresponding actions by the Nazi state.*

On I April 1933, reacting to the state-incited boycott of Jewish shops and the cleansing of Jews from public offices, the Swedish daily Dagens Nyheter speaks of 'a crime against civilisation'. 1 The next day, in the same newspaper, a member of the Swedish Supreme Court, Nils Alexandersson, speaks of a crime against the very foundations of the Western world. ${ }^{2}$ Again, a few weeks later, the journalist and writer Torsten Fogelqvist sees, in the events in Germany, a retreat of mankind to prehistoric times. ${ }^{3}$

There is hardly a public comment in Sweden these days that does not evoke similar associations and premonitions, stressing the point I wish to make: there was no escaping the pan-buman significance of what was happening to the Jews of Germany. There might have

* Presentation at the Centre for the Study of Jewish Thought in Modern Culture, Copenhagen, 5 May 2015.

1 Dagens Nyheter, I.4.I933, this and following quotations are from Judisk Tidskrift, April I933.

2 Ibid., 2.4.I 933.

3 Ibid., 2.4.I 933 . been those hoping that it would all soon pass, like a nightmare, that the persecution of the Jews would turn out to have been but a temporary, if ugly, means to power, yet most seemed to have understood that they were witnessing a civilisational rupture of sorts, something that touched not only the conditions of the Jews of Europe but the human condition as such. 'The whole civilised world and all thinking people are appalled about the news coming out of Germany these days', wrote the Christian weekly Sanningsvittnet on 6 April r933.4 'One almost fears that the whole of mankind is sliding back into barbarism', wrote the liberal daily Eskilstuna-Kuriren on 3 April. 'A more distinct act of barbarism cannot be imagined!', wrote the Social Democratic daily Oscarshamns Nyheter on 3 April. 'To such barbarism it would be hard to find an equivalent even in medieval times', wrote Östersunds Länstidning on 3 April. And on 16 April I933, in Vecko-Journalen, the writer Erik Lindorm: 'Father don't forgive them, because they know what they do.' Fader forlàt dem icke. Ty de veta vad de göra.

And so forth and so on.

On 26 April 1933 a proclamation against antisemitism was published in several Swedish newspapers, signed by a number of prominent Christians of various denominations, including several bishops and professors, stating that any measure aimed at the demeaning of the Jews and their exclusion from full civil rights was in

4 Sanningsvittnet, 6.4.I 933. 
relentless opposition to the spirit and teachings of Jesus'. 5

It seems safe to say, then, that the very first actions against the Jews in Germany were perceived as an affront not only to Jews, but to Western civilisation at large, and that what was happening was well publicised all over Europe. Most people knew about it, and judging by reactions and comments, most people were truly shocked by it.

The deeper human significance of making race and biology the all-determining factors of human existence, abolishing the notions of moral choice and spiritual freedom, did not escape the French Jewish philosopher Emmanuel Levinas, when in 1934 he published a short reflection on the philosophy of Hitlerism, as he called it. 6 By declaring the category of race a biological prison with no spiritual escape, the Hitler ideology was a fundamental break with the basic tenets of human existence. What was at stake was not a political or religious doctrine of one sort or another, but the very humanity of the human being, l'bumanité même de l'homme. ${ }^{7}$

To this can be added an immediate outburst of international proclamations and protests and demonstrations, and even counter-boycotts, all over Europe, which goes to show that the immediate and brutal implementation of anti-Jewish policies in Germany seems to have made a deep impact on most Europeans at the time. It is also reasonable to presume that such a widely shared shock must have left a deep imprint on the minds and memories of those living at the time.

In any case, these events cannot have been easily forgotten, since they were soon to be followed by new events, giving rise to new shocks. Public comments and reactions to the racist

\footnotetext{
5 Reprinted in Judisk Tidskrift, April I933, p. I 26.

6 Emmanuel Levinas, Quelques réflexions sur la philosophie de l'bitlérisme, L'Esprit, 2, I 934

(Paris, Éditions Payot \& Rivages, I 997).

7 Ibid. Iо.
}

Nuremberg Laws of 1935, making people of Jewish descent a sub-human category, were, if anything, even more widespread and outraged, again making the Nazi persecution of the Jews an affront to human civilisation as a whole. This can no longer remain a German internal affair, wrote one Swedish commentator; 'no country or people can be allowed to defy the general sense of justice in the world'. 8

It is true that some wished to explain it all away as the result of a specifically German madness or poisoning, something that normal Swedes could not possibly grasp or understand, 9 but again, it was still considered shocking that Germans, people very much like ourselves, could do such things. And in November 1938 these Germans could do even more: burning, plundering, killing and making a mockery of any pretences to legality, prompting even a nationalist and pro-German magazine, Nationell Tidning, to express its fears that Germany would become internationally isolated. 'All our admiration for German culture and for the great contributions and social achievements of its people these last years cannot extinguish our human feelings', the paper wrote. 10

'The question of the Jewish People, judafolket, has become the issue of mankind as a whole', stated the archbishop of Sweden, Erling Eidem, in a public appeal on behalf of the Swedish Church in December i 938. (I will return to Eidem in a moment.)

All this goes to show, I think, that we are dealing with a series of events that deeply shocked people at the time, even people with no or little sympathy for the Jews as such. There is clearly a sense of a rupture in human civilisation coming through in these comments, of a fundamental

8 Bernhard Johansson in Svenska Morgonbladet, 8.8.1935.

9 Stockholms-Tidningen, I6.9.1935.

10 Docent Elmo Lindholm in Nationell Tidning, I 9. I I.38, quoted from Judisk Tidskrift, November 1938. 
break with deeply rooted notions of humanity, not to mention deeply rooted religious beliefs and ideas. In particular, a shock-wave is seen to be going through the Christian world, with its strained and poisoned relationship to Jews and Judaism on one hand and its moral self-understanding on the other. It is safe to say that the Nazi onslaught on the Jews, mobilising every anti-Jewish trope in the Christian tradition to defy the foundations of Christianity itself, was a defining event for millions of people who regarded themselves as good Christians, forcing them to face the very core of their Christian beliefs. All too many would accommodate their Christian beliefs to the new Nazi morality, but even so it must have taken an inner value struggle to get there, making it a strong and presumably widely shared emotional experience, from which at the end of the day the stuff of collective memories is spun.

If later people would say they weren't aware of what was happening to the Jews in Germany in I 933 or 1935 or 1938 , then this was not because they did not know or remember, but because there was to be a parallel process of adaptation and normalisation, numbing minds and silencing conversations. One may presume that the relentless Nazi state propaganda against the Jews contributed to this process of moral attrition, as did the on-going consolidation of Nazi power, and the growing fear of it. Normality was established on a new moral plane, one might say, or in a new moral universe. The Swedish author, Agneta Pleijel, reminiscing about her childhood in a family with diverging views of the events in Germany, with some parts of the family becoming increasingly sympathetic to the Nazi regime, notes that the topic was soon banned from family discussions to avoid tension and irritation. ${ }^{11}$ One may observe a similar process of conflict avoidance taking place in the public domain, in

\footnotetext{
11 Agneta Pleijel, Spådomen (Stockholm, Norstedts, 2015), p. 84.
}

which initial expressions of shock and dismay were soon to be replaced by expressions of adaptation and accommodation, sometimes by the very same people. The well-known sports-writer Torsten Tegnér, who in I 933 had exclaimed that Germany was not fit to host the Olympic games of 1936 , would in 1936 become an enthusiastic propagandist for those very games. ${ }^{12}$

Soon also, the idea that Jews fleeing Nazi Germany should be given even temporary asylum in Sweden became a contentious issue. When in 1933 a public appeal was made for help for intellectual refugees from Germany ('från Tyskland landsflyktiga intellektuella'), signed by two members of the royal family (princes Eugen and Wilhelm) and a large number of prominent Swedish cultural figures, it was made clear that there could be no talk of making room for 'these refugees within our country, in times when unemployment is such a big problem'. Nowhere in the appeal is the word Jew to be found, although there was little doubt of which people were meant. The same omission can be found in other appeals and commentaries - as if the word Jew had already been contaminated by Nazi propaganda and would serve to undermine the power of the aid appeals. Very soon, then, the initial moral shock is riddled with moral ambiguity and distress, and the link between experience and memory is weakened. Or rather, the collective process of confirming and reconfirming that what you remember is what other people too remember, is hampered by conflict and fear.

Paul Ricour has proposed that such a process largely takes place on an intermediate level of reference, le plan intermediaire, a level of human communication at which we exchange our individual memories of specific events with

12 Torsten Tegnér in Idrottsbladet, April I 933: 'Hängivna Olymper må icke acceptera en Olympiad i ett land, där en av jordens mest spridda och bevisligen effektivaste raser systematiskt undertryckes och förföljes.' 
the memories of friends, acquaintances and more generally people we trust. 13 This is then presumably also a process in which an initially strong reaction on the individual level may be collectively subdued and suppressed, giving cause for an undercurrent of disquiet and discomfort, which at times comes to the surface as in a commentary in Göteborgs-Posten: 'Why do we keep silent in face of the humiliation and injustice that is brought on the Jews of Germany day after day?' Or as in the question by the wellknown social activist and Christian publicist, Natanael Beskow, in an article in Dagens Nyheter in November 1938: 'Are we prepared to take the consequences of our moral indignation?'14

Even within the Jewish community itself, there was soon a tension created between outrage and adaptation, between the desperate urge to help the fleeing Jews of Germany, and the fear of stoking antisemitism by doing so. More specifically, a rift was opening up between the old Jewish establishment, torn between its proverbial 'dual loyalties', and an increasingly activist Zionist group with its roots in more recent waves of Jewish immigrations. In I 936, a well-known member of the established Swedish Jewish community, professor Ragnar Josephson, in a printed address to the Jewish congregations in Stockholm and Gothenburg argued for the need to maintain confidence in 'our uncompromising national reliability' and therefore to act with restraint on the issue of Jewish refugees. 'It is beneficial to a country to incorporate a few "honest men"', Josephson wrote, but damaging to receive 'larger groups of foreign citizens ... who by their alienation and numbers will create suspicion, distress and disorder.'15

13 Paul Ricœur: Minne, historia glömska (Göteborg, Daidalos, 2005), p I 77.

14 Natanael Beskow: 'Hur reagera vi?', Dagens Nyheter, reprinted in Judisk Tidskrift, November I 938, p. $35^{\circ}$.

15 Ragnar Josephson: Den dubbla lojaliteten
On 7 July 1933, Dr Hugo Valentin, a respected Swedish Jewish historian and a leading Zionist activist, in a private letter gave voice to his deep frustration with the perceived reluctance on the part of the Jewish leadership to accommodate a group of German Jewish children for the summer, seeing it as 'a lack of solidarity, of human empathy, bordering on the shameful'. 16

After the war, Hugo Valentin would deny the existence of a moral rift within the Jewish community in Sweden, maintaining that differences of opinions were about means only, not about the goal, to make governments act more generously towards the refugees:

There is no foundation for the statements made now and then, that the leadership of one of the largest Scandinavian Jewish communities had taken an unfriendly position with regards to the refugees ... Were it possible in those years to foresee the full development of the Nazi activities, no doubt both the Jews of the Scandinavian countries and the governments would have acted differently. To judge them harshly today is unfair. 17

(Stockholm, Albert Bonniers Förlag, I936), pp. I3-I 4 .

16 With thanks to Fabian Sborovsky who shared a facsimile copy of the full letter, written in Swedish and quoted in his MA thesis: 'A Revised Examination of the Legacy of Marcus Ehrenpreis and its Relevance for the Twenty-First Century European Jewish Diaspora' (Nashville, Vanderbilt University, 2009).

17 Hugo Valentin, Rescue and Relief Activities on Behalf of Jewish Victims of Nazism in Scandinavia, YIVO Annual of Jewish Social Science, vol. VIII (New York, Yiddish Scientific Institute, I 953), p. 226 . See also Pontus Rudberg: The Swedish Jews and the Victims of Nazi Terror, 1933-1945 (Uppsala, Acta Universitatis Upsaliensis, 2015), arriving at similar conclusions. 
The difference in tone and position between Valentin in 1933 and Valentin in 1953 can of course be explained by the difference between a private letter and a published article, but perhaps more, I would argue, by the difference between an unmitigated expression of individual moral outrage and a negotiated suppression of collective shame and humiliation. Although Valentin, like most people, not only within the Jewish community but in society at large, were deeply and visibly shocked by the events in Germany, they were all in fact part of a society that would be marked by far-reaching moral accommodation and moral complicity - and therefore, in due time, by a collective process of forgetting or suppressing that which was too disturbing or even painful to remember. Between the moral outcry provoked by the enormity of the events in Nazi Germany, and the on-going adaptation of actions and opinions to a new Nazi morality, there seems to be a chasm opening up between individual experience and collective memory, between memory recorded at the time, and what society later wished to remember - or rather to forget.

Wherever we may search in the recorded memories of these years we may thus discover seeds of what I would call collective shame. It is true, as Hugo Valentin notes, that the ultimate steps in the Nazi policy of annihilation against the Jews would only be known later, but as I have tried to show, already the very first actions against the Jews of Germany were widely regarded as a crime against the most basic rules of human morality, or as it would later be called, a crime against humanity. Out of impotence or convenience or acceptance or downright collaboration, many people in Europe would do things or believe things that later they would rather forget. Suffice it to mention the conference in Evian in the summer of 1938 , in which the nations of the world effectively closed their borders to the Jews, who still had a chance to save themselves from total annihilation.
Let me also just briefly go back to the archbishop of Sweden, Erling Eidem, who in November 1938 signed an appeal for assisting Jewish child refugees, but who during the war refused to publicly criticise Nazi Germany, apparently in order not to endanger the Swedish policy of neutrality, putting the interests of the state before the values of the Church, if you like. Eidem himself was clearly disturbed by anti-Jewish tendencies within the Church itself and there is evidence that he took issue with them in private letters and admonitions, but as Steven Koblik summarises Eidem's position: 'When faced with the dilemma of defending the church as a social-political institution or sustaining the role of the church as the moral leader of the society, Eidem chose to be a bureaucrat rather than religious leader.'18 Koblik adds the all-important rhetorical question: 'How many other churchmen made the same decision?'

All in all, we may note a process in which an immediate reaction of shock and disgust is suppressed, giving way to a collective memory increasingly formed by accommodation, resignation, indifference and outright collaboration, and when the winds of war turn and the spell of Nazi power is broken, a collective narrative is formed by a sense of shame and guilt, and soon by a desire to forget and move on. The promise of 'never again' may from this perspective be understood both as an expression of shame and guilt, and as a permission to forget and move on.

\section{The wall of silence and shame}

In my book A Brief Stop on the Road from Auschwitz, a childhood memoir of my father, a survivor of the Shoah, there is a wall. Not a wall of stone but a wall of guilt and shame, or in any case a wall beyond which I imagine the memory of my father is no longer able to reach. Or

18 Steven Koblik: The Stones Cry Out (New York, Holocaust Library, I 988), p. I I 4. 
at least a wall beyond which I cannot reach my father's memories, a wall erected by events and experiences so devastating and humiliating that they could not be survived without being suppressed. As an example I take the events occurring in the ghetto of Łódź in September I 942, when the children, the sick and the elderly were to be delivered to the Germans, or as the chairman of the Jewish Council, Chaim Rumkowski, put it, to be sacrificed, so that the still ablebodied and strong might be saved.

'How can we be expected to live on after this?' the Łódź ghetto diarist Josef Zelkowicz asks, after having witnessed the events of September I 942. ${ }^{19}$ The diary would outlive Zelkowicz, who died in Auschwitz, and so would the question.

It would live on, I believe, as a question binding together perpetrators, bystanders and surviving victims in a suppressed memory of shame. The survivors, by the shame of having survived the most sinister and effective process of humiliation and dehumanisation ever designed, and the perpetrators and bystanders by the shame of having designed, executed or merely witnessed it. In his last book, The Drowned and the Saved, Primo Levi speaks of 'the shame of the world', of 'those, who faced by the crime of others or their own, turn their backs so as to not see it and not feel touched by it.'

Seen in this perspective, the Nazi crime was a great leveller. It shamed humanity as a whole, or at least the idea of humanity as it had evolved in the Judaeo-Christian tradition and imagination. It thus created a moral anomaly, or moral monster if you like, that left its mark on all too many people with all too many reasons for not wanting to remember what they had only recently been a part of or witness to.

Even 'the just among us', Levi writes, 'felt remorse, shame, and pain for the misdeeds that

19 Josef Zelkowicz, In Those Terrible Days: Notes from the Eódź Ghetto (Jerusalem, Yad Vashem, 2002). others and not they had committed, because they sensed that what had happened around them and in their presence, and in them, was irrevocable. Never again could it be cleansed; it would prove that man, the human species we, in short - had the potential to construct an infinite enormity of pain, and that pain is the only force created from nothing, without cost and without effort. It is enough not to see, not to listen, not to act.'20

In the story of my father, as I tell it, this is what he also has to survive: the shame of having survived into a world that does not want to see and listen and act:

Like Lot's wife, people in your situation can go on living only if they don't turn around and look back, because like Lot's wife, you risk being turned to stone by the sight. Nor, however, can you go on living if nobody sees and understands what it is you've survived and why it is you're still alive, in spite of everything. I think the step from surviving to living demands this apparently paradoxical combination of individual repression and collective remembrance. 21

\section{Narratives of remembrance}

Eventually, the world would start looking back again. It took the passing of a generation or two; the specific events and actions that led to this change in Western collective memory are manifold, and it is hard to say if it was bound to happen or not. It was not even clear that it was bound to happen in the new-born state of Israel, where the events of the Shoah were associated for a decade or more with humiliation and shame, with the Jews 'going like sheep to the

20 Primo Levi, The Drowned and the Saved (New York, Summit, I988), p. 86.

21 A Brief Stop on the Road from Auschwitz, trans. Sara Death and John Cullen (New York, Other Press, 2015). 
slaughter', as it was said, and were seen as an embarrassing element in an emerging narrative of Jewish heroism and rebirth, with the heroic ghetto uprising in Warsaw in April 1943 as the only event worth commemorating.

Eventually, the Holocaust as a whole would be incorporated into the narrative, making Holocaust Remembrance Day, Yom Ha'shoah, the chronological and 'national-theological' precursor to Commemoration Day, Yom Ha'zikaron (to the soldiers fallen in the battles for Israel), and Independence Day, Yom Ha'atzmaut. This would in time make for a distinctively Israeli Zionist narrative of the Holocaust: as the ultimate raison d'être of the Jewish State, as the ultimate memento to the Jews of their perilous existence outside it, and as the ultimate justification for whatever policies the state of Israel might deem necessary in order to avert another holocaust. When the Israeli prime minister Benjamin Netanyahu spoke at the commemoration of Yom Ha'shoah in 2015, he explicitly (and not for the first time) compared the threat to the Jews from present-day Iran with the threat from the Nazi regime:

Just as the Nazis aspired to crush civilisation and to establish a 'master race' to replace it in controlling the world while annihilating the Jewish people, so too does Iran strive to gain control over the [Middle East] region, from which it would spread further, with the explicit intent of obliterating the Jewish state.

He also evoked the number of six million to equate the Jewish victims in the Nazi Holocaust with the Jewish victims of a threatening Iranian follow-up. 22 In this narrative, the Nazi Holocaust was made possible by Jewish weakness

22 Quoted from <http://www.jns.org/ news-briefs/201 5/4/16/on-yom-hashoahnetanyahu-compares-iran-to-nazi-germany\#. $\mathrm{VUTeSc}_{5} \mathrm{anf}_{4}=>$. while the Iranian Holocaust will be prevented by Jewish power. Or to quote Netanyahu once more: 'Seventy years ago, we were a nation of helpless refugees - today we can speak for ourselves... Our job is to fight those who want to destroy us.' This way of using (or abusing) the memory of the Holocaust for legitimising and justifying almost any use (or abuse) of Israeli power has become a dominant feature in the political rhetoric of present-day Israel, and by extension, of parts of the Jewish Diaspora, where manifestations of antisemitism have been associated with the march of events in the r 930 and have thereby been served up as an argument for admonishing the Jews of Europe to pack their bags and take refuge behind the barricades of a well-armed Jewish state.

Some scholars have called this the instrumentalisation of Holocaust memory, making historical memory serve a current political agenda, and no doubt this is what we see happening in Israel, although it is hard to see how it could be otherwise. In any Jewish context, whether in Israel or not, the memory of the Holocaust will inevitably give rise to 'an inexhaustible reservoir of images, arguments and assertions', to quote the Israeli historian Idith Zertal. ${ }^{23}$ Furthermore, it is hard to see how any narrative of the Holocaust, Jewish or not, can avoid being instrumentalised in one way or the other. There is no memory without narrative, and the narratives emerging from the 'inexhaustible reservoir of images' of the Holocaust will always serve contemporary purposes, whether we recognise it or not. We may argue that some purposes are more befitting than others, and I certainly think that a narrative of fear and power is a problematic one, but there is no way of cleansing Holocaust memory of purpose, and no way of avoiding the questions

23 Idith Zertal, Israel's Holocaust and the Politics of Nationhood (Cambridge University Press, 2005). 
of why remember, and what to remember, and how to remember.

There is, no doubt, a case to be made for a specific Jewish narrative of the Holocaust, and even for a specific Jewish narrative of fear and power; the Holocaust happened, after all, and it happened to the Jews, and it could perhaps only have happened to the Jews. Also, there are no signs that antisemitism will go away any time soon, and enough signs that it can all too easily be reawakened, and therefore there is still reason to be fearful of its consequences.

\section{From shame to dignity}

Nevertheless, I believe this to be a narrative that belittles the universal significance of Holocaust memory, first and foremost by providing too narrow an answer to the question of why we should remember the Holocaust, and thereby also to the questions of what to remember and how. It is a narrative that remembers the Holocaust as a catastrophic event in a long historical chain of Jewish disasters - which it certainly is - but which thereby fails to recognize the Nazi years as a catastrophic rupture in Western civilisation as a whole. It thereby tends to give scant attention the grey zone, as Primo Levi calls it, that zone of moral accommodation and corruption inhabited not only by the perpetrators and the bystanders but by the surviving victims as well, however unwittingly. It thereby also tends to block out the memory of shame. In a narrative of pre-defined penetrators and pre-defined victims, there is no room for shame.

As I have tried to show, the universal moral outrage at the Nazi regime did not come with Auschwitz, it came with the very first actions and decrees against the Jews in April and May of r 933, and it was reawakened again by the Nuremberg Laws in 1935 and the November pogroms in 1938 . And with it came the all-pervasive human shame of having lived in a society which could or would not prevent this from happening, and in which too many accommodated themselves to the inversion of their moral universe, and to the radical perversion of deeply ingrained values defining the very notion of what it means to be a human being.

In this sense, the Nazi regime did not only humiliate its victims, but through implication, accommodation, coercion and conviction, almost everybody else living in the Nazi sphere of power and propaganda. The promise 'never again' was not only about the victims but about the perpetrators and bystanders as well. 'Never again' would we allow this to happen to our societies and to ourselves. The Universal Declaration of Human Rights of I945, I would argue, was largely born of a sense of human shame and a craving for human dignity, or as it says in the very first sentence in the preamble to the declaration, 'the inherent dignity and ... the equal and inalienable rights of all members of the human family is the foundation of freedom, justice and peace in the world'.

This, of course, makes for a somewhat different narrative of the Holocaust, emphasising its pan-human significance, providing the ultimate argument for the necessity of global institutions and conventions and the ultimate warning against the re-emergence of policies based on nationalism, xenophobia and racism.

It is also a narrative of before and after. Before, we did not have to live with the shame of Auschwitz. After, we must. Or rather, we should.

\section{Why remember?}

I prefer 'should', since I do not think that it is evident that the Holocaust must be remembered in that special way which we today consider proper - or even necessary that it should be. The Holocaust is an event in history and like all events in history it will pass from living memory to historical memory, and to future generations it will become increasingly distant in time and eventually cease to be a part of living memory. 
Nevertheless, I would argue that a particular effort should be made to retain the Holocaust in living memory, or rather to make Holocaust remembrance a formative individual collective experience for generations to come.

I am not saying it must happen or even that it could happen, but I think there is a particular reason for why we should make the effort, and that I believe is that all-pervasive human shame that the Nazi project generated in our civilisation, and which we would do well to keep in living memory. It is against the backdrop of shame that the notion of dignity gets its meaning.

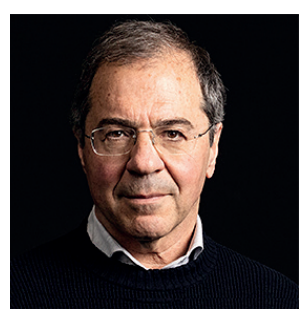

Göran Rosenberg is a Swedish journalist and author. His parents were survivors of the Holocaust who settled in Sweden. Rosenberg's book A Brief Stop on the Road from Auschwitz (Stockholm, Bonniers, 2012) is based on his father's story and his childhood. The book has been translated into several languages and it is a winner international awards. In addition to Swedish newspapers and journals, Rosenberg's essays and articles have been published in, for example, Neue Zürcher Zeitung, Süddeutsche Zeitung, Lettre Internationale, Daedalus, New Perspectives Quarterly, The New York Times and Eurozine. 